Published in Proceedings of the ICSB 2017 World Conference, Buenos Aires, Argentina, June 28 July 1 2017, which should be cited to refer to this work.

\title{
External financing perceptions by Sub-Saharan Entrepreneurs: a Qualitative Approach
}

\author{
Jean-Michel Sahut ${ }^{a}$, Eric Braune ${ }^{b}$ \\ a IDRAC Business School (France) \& HEG Fribourg, HES-SO // University of Applied Sciences \\ Western Switzerland \\ b INSEEC Lyon (France)
}

\section{Objectives of the paper}

While Africa is often described as a continent whose economic growth is promising, it is very difficult to find studies on the survival rate of young African businesses. Moreover, factors explaining the influence of initial creation conditions of on the survival of these companies are not clear. In literature, various works have focused on company survival and highlighted factors likely to encourage it (Boyer and Blazy, 2014; Simón-Moya et al., 2012), such as market factors, financial factors, factors related to life-cycle, personal characteristics of the entrepreneur, access to external financing, regional specificities, and social capital. Among the reasons for discontinuation of young businesses, the Global Entrepreneurship Monitor report (2014) stresses that the lack of external financing is still more important in the African economies than in the rest of the world. Thus, while the large privatization of the Sub-Saharan banking sector stimulates the 
creation of easily mobilizable savings, promotes an efficient allocation of capital and raises the total factor productivity (Montfort et al., 2016), Beck and Cull (2013) indicate that Sub-Saharan African enterprises are less likely to use financial services than their peers in other developing countries. Therefore our study explores the factors explaining why Sub-Saharan entrepreneurs are prone to reject debt financing of their ventures.

\section{Methodology}

The qualitative research approach we conduct allows us to understand how Cameroonian entrepreneurs interpret their experiences, how they construct their worlds, and what meaning they attribute to their experiences. The choice of this methodology is also justified by its ability to generate comprehensive information to determine entrepreneur perceptions of the impact of bank loan at the early stage of a firm and the factors needed to access it.

In this context, extensive interviews were conducted between November 2014 and February 2015 with 18 entrepreneurs selected according to three criteria:

\section{- Survival}

following Dumez (2009) we differentiate Entrepreneurs whose company's survival is less than three years, from three years to five years, and more than five years. Our sample contains six entrepreneurs for each category,

- The amount of bank loans

we chose at least one entrepreneur per category that did not have recourse to bank loans during the creation phase of his (her) venture,

- Firm size 
based on sales, each category is composed of companies with sales below XOF 10 million (16 500\$), two having sales between XOF 10 and 100 million, and two with sales above XOF 100 million.

Each interview took place over a period of one hour on average. At the beginning of every interview, interviewees were given a guarantee of confidentiality regarding their identity and data provided. All interviews were recorded and reviewed several times before being transcribed in full. Four areas were addressed: (1) the reason for the use or non-use of bank loans at the time of the creation of their companies; (2) the bank loan procedure at the company creation time; (3) relationships with a banker at the company creation time; (4) the role of bank loans and their volume at the time of company creation and their impacts on firm survival. To analyse the data, we applied best practices in qualitative research, such as those promoted by Miles and Huberman (1994). We followed the following four steps: (1) coding of the interviews: codes were assigned to units of meanings, which could be phrases, sentences, or even paragraphs. This step permitted us to identify emergent themes through the use of NVivo; (2) defining tabulation: we used a tabular display to facilitate the analysis of our qualitative data. We built a matrix using our codes to cluster information around topics; (3) comparison and identification of patterns: our matrix enabled us to identify patterns and contrast and compare between entrepreneurs' perceptions; (4) closing of the study and analysis. We reached theoretical saturation at around 14 interviews. To make sure we were not missing any key elements, we conducted additional interviews.

\section{Results}

The analysis of semi-structured interviews with entrepreneurs resulted in for main categories of perceptions that influence the entrepreneur willingness to resort to external financing: (1) self- 
censorship; (2) reluctance to meet banks requirements; (3) absence of profit maximization concern; and (4) importance of the entrepreneur social capital to access bank loan.

\section{Self-censorship}

A non-bank loan is, most of all, a choice of the entrepreneur. In the reasons given for non-bank loans, refusal of a request for loan by banks is discussed in a limited manner. Entrepreneurs note a type of self-censorship (i.e. they believe that bank loans are not adapted to their case or that their bank is going to deny them funding), a lack of borrowing need, or a refusal to go into debt. The entrepreneurs who say they voluntarily do not use bank financing because they do not have the need or desire to enter debt usually develop small projects with their personal funds. This censorship is much stronger for very small businesses (VSBs) than other SMEs. These entrepreneurs acknowledge, however, that they often underestimated their financing needs and have had to make additional investments in the first six months of company creation. By investing the bulk of their savings, the company creators run out of 'reserves' to cope with unforeseen events.

\section{Reluctance to meet banks requirements}

Entrepreneurs have divergent opinions on access to bank loans. On one hand, Entrepreneurs often find personal questions from bankers regarding their motivations to create, and their life, which are designed to glean information and thus have a better understanding of their customers, to be intrusive. In fact, the banker in his first interactions seeks for tangible and intangible elements allowing him to reach a minimum confidence level to establish a loan record having a reasonable 
chance of acceptance in order not to waste time. Moreover, VSB entrepreneurs note that access to bank loans is difficult because banks require detailed information about a business plan, management of the future company, forecasts, and how the loan will be repaid, which they are not able to provide. They perceive a particular pressure from banks on their ability to pay debts in the short term. Banks also request information on project stakeholders mobilized within the social network, and whose reputation will shed light on the quality of the approach and the seriou sness of the entrepreneur. On the other hand, larger-sized entrepreneurs believe that the requirements of banks to form their loan applications have helped them better financially structure their project. Particularly, they often had to amend provisional elements and improve financial projections in their business plans. The involvement and reputation of their accountants in this process also play an important role. These results are consistent with those of Bastié, Cieply, and Cussy (2011), in the French context. This indicates the need for involvement of entrepreneurs in their firm financing. The disciplinary role of banks is also highlighted in Minnis and Sutherland (2016) and Diamond (1991). Access to bank loans also depends on the amount of capital raised initially by the entrepreneur and his/her family. This must reach a certain level to be credible, and has to make possible loan access.

\section{Absence of Profit maximization concern}

For VSB entrepreneurs, the rational maximization of profit is not their main concern. They seek to ensure the survival of their firms than achieve profitability, and have suboptimal behavior towards partners with which they 'like' to work. The importance of the networks formed by these entrepreneurs is also reflected in the choice of bank for their loans. They remain loyal to their banks, and they do not seek the best offer by putting banks in competition. 
According to our analysis, the human dimension in the first two conversations between banker and entrepreneur, at the time of the request for loans for business creation, is an important element influencing the continuation of the relationship and the procedure for loan applications. Our discussions also mentioned the problem of trust in the relationship between the banker and the entrepreneur, except for serial entrepreneurs.

As noted by the literature in this area, trust builds with the interactions between the players, but the paradox of the need for a minimum trust level to initiate the actors' interactions is almost never discussed (Jayawarna et al., 2011). This trust level is based on a minimum level of knowledge of the players.

\section{Access to bank loan is conditioned by the entrepreneur's social capital}

The entrepreneurs view social capital as an element used to convince bankers of the success of their businesses. Particularly they think that the banker is especially sensitive to financing networks, the integration of entrepreneurs in business networks, and their ability to recruit the right people. Therefore, financing networks will determine the future financing structure. The banker seeks to assess the future sources of funding available and possible risk transfers from shareholders to borrowers. The social capital thus lends credibility to the project, to create trust in the banker, and, ultimately, improve loan access. 


\section{References}

Bastié, F., S. Cieply, and P. Cussy. 2011. "The Entrepreneur's Mode of Entry: The Effect of Social and Financial Capital.” Small Business Economics 40 (4): 865-877.

Beck, T., and Cull, R. 2013. "Banking in Africa." World Bank Policy Research Working Paper $n^{\circ} 6684$.

Boyer, T., and R. Blazy. 2014. "Born to Be Alive? The Survival of Innovative and NonInnovative French Micro-start-ups.” Small Business Economics 42 (4): 669-683.

Diamond, D. 1991. "Monitoring and Reputation: The Choice between Bank Loans and Directly Placed Debt.” Journal of Political Economy 99: 688-721.

Dumez, H. 2009. “Identité, performance et pérénnité organisationnelle.” Revue Française de Gestion 35(192): 91-94.

Jayawarna, D., O. Jones, and A., Macpherson. 2011. "New Business Creation and Regional Development: Enhancing Resource Acquisition in Areas of Social Deprivation." Entrepreneurship \& Regional Development 23 (9-10): 735-761.

Miles, M., and M. Huberman. 1994. An Expanded Sourcebook - Qualitative Data Analysis. Thousand Oaks, CA: Sage.

Minnis, M., and A. Sutherland. 2016. "Financial Statements as Monitoring Mechanisms: Evidence from Small Commercial Loans.” Journal of Accounting Research, published online DOI: $10.1111 / 1475-679 X .12127$

Montfort, M., Cui, L.Q., Jidoud, A., Newiak, M., Radzewick-Bak, B., Takebe, M., Ye, Y., and Zhang, J. 2016. "Financial Development and Sustainable Growth.” Regional-Economic Outlook; Sub-Saharan Africa, International Monetary Fund: 51-78. 
Simón-Moya, V., L. Revuelto-Taboada, and D. Ribeiro-Soriano. 2012. "Are Success and Survival Factors the Same for Social and Business Ventures?" Service Business 6 (2): 219-242.

Tchankam, J. P., J. Feudjo, R. Gandja, and S. Valant. 2016. "The Determinants of Financial Structure: How to Explain the 'Paradox of Insolvency and Debt" among SMEs in Cameroon?" Research in International Business and Finance 36 (1): 73-84.

Teurlai, J.-C. 2004. "Comment modéliser les déterminants de la survie et de la croissance des jeunes entreprises?" Cahier de Recherche 197 du Centre de Recherche pour l'Étude et l'Observation des Conditions de Vie, Février.

Uphoff, N. 2000. "Understanding social capital: learning from the analysis and experience of participation.” In Social Capital: A Multifaceted Perspective, edited by P. Dasgupta, and I. Serageldin, 215-249. The World Bank: Washington, DC.

Uzzi, B. 1999. "Embeddedness in the Making of Financial Capital: How Social Relations and Networks Benefit Firms Seeking Financing.” American Sociological Review 64 (4): 481-505.

Vos, E., and C. Forlong. 1996. "The Agency Advantage of Debt over the Lifecycle of the Firm." Journal of Entrepreneurial and Small Business Finance 5 (3): 193-211.

Weinberg, J. A. 1994. “Firm Size, Finance, and Investment.” Economic Quarterly 80 (1): 19-40.

Weinstein, D., and Y. Yafeh. 1998. "On the Costs of a Bank-centered Financial System: Evidence from the Changing Main Bank Relations in Japan.” Journal of Finance 53 (2): 635-72.

Westlund H., and F. Adam. 2010. "Social Capital and Economic Performance: A Meta-analysis of 65 Studies.” European Planning Studies 18 (6): 893-919. 